struction. The difference between consumers estimates and the estimates of business men in this matter arouses a certain amount of scepticism about the estimates of business men on which other conclusions in the report are based. One wonders, for example, how consumers estimates of post-war purchases of domestic appliances, motor-cars or furniture would have compared with the business estimates of sales for these commodities had the business schedules asked for sufficient detail of this sort.

The Kitchener-Waterloo survey is based on the assumption that the end of the War will see a return to the operation of consumers demand in a conapletely uncontrolled economy. So far as Great Britain is concerned, at any rate, it is doubtful if such conditions will prevail during the immediate post-war years. It has been said that "the guiding principle with regard to the production and distribution of consumption goods, will be to secure, so far as possible, that labour and capacity no longer needed for munition production shall be used for producing civilian goods of high priority-until the primary needs are met, resources which could be applied to meet them should not be diverted to the production of luxuries for home consumption".

This will need detailed information about stocks and needs. Much war-time administrative action has been based on such detailed information of basic needs. Information collected on a national scale would complement the regular censuses of production and national income and expenditure accounts which are promised, and would, in a short time, provide a sufficient body of data on buying habits to act as a complete check on the consumers' estimates.

There will be inevitably many successors to this survey. It is a useful job well done, and future workers in this field will certainly benefit from careful study of the methods used and the results.

(The survey has not so far been put on sale to the public, but the Canadian Chamber of Commerce has made some copies available to interested bodies.)

L. Moss.

\section{SCIENCE IN CANADA AND SOUTH AFRICA}

$\mathrm{T}$ HE third of a series of discussions on the organisation of scientific research in the British Commonwealth, arranged by the Society for Visiting Scientists, was held at the Society's House at 5 Old Burlington Street, London, on January 9, with Dr. C. S. Hanes, director of the Food Investigation Department, Department of Scientific and Industrial Research, in the chair. The speakers were: Dr. W. E. van Heyningen, assistant director of the Wellcome Physiological Research Laboratory ; Major E. Boden, Council for Scientific and Industrial Research, Canada; Dr. R. Y. Stanier ; Dr. J. G. Malloch, chief scientific liaison officer for Canada; Dr. W. Cullen; Colonel J. H. de Boer, deputy chief of staff, Netherlands Military Administration; Colonel Marquad, head of Army Education Services in South Africa; and Colonel O. M. Solandt, director of Scientific Defence, Canada.

Canada, being the oldest Dominion, also enjoys the most elaborate research organisation. As its primary and oldest industry is agriculture, it was in that field that research was first applied. Dr. William Sanders and Sir Charles Sanders were jointly responsible for the discovery of a new variety of wheat which revolutionized agriculture in North America. This encouraged the Department of Agriculture to estab. lish a vast research organisation with experimental stations all over the country, and special laboratories covering every branch of agricultural science. One of its latest successes has been the reduction of loss from wheat rust. The Department of Mines and Resources deals with the exploitation of natural resources, including sylviculture, forest products, timber utilization as well as minerals. There is a strong Fisheries Research Board, and a Grain Research Laboratory under the Department of Trade and Commerce.

The National Research Council was not established until 1915. Since then, it has achieved, through a system of associated committees, a large measure of co-ordination between different institutions in the country, which has been very valuable, among other things, in mobilizing Canada's scientific resources for war purposes.

However, Canada has a serious problem in the loss of so many of its scientific men, mainly to the United States. The question of the isolation of scientific workers, which has been stressed in all the former discussions on other regions of the Commonwealth, is also a problem in Canada, particularly in the west, and here their southward drift is a natural but undesirable result. The remedy is to improve the conditions of scientific research in Canada and to enlarge university staffs, thereby not only reducing the individual teaching load, but also opening up new fields of teaching and research such as genetics, microbiology, biochemistry, oceanography, etc. Industrial research has so far been relatively neglected in Canada, since all the larger companies are subsidiaries of American firms, and research work is done in the United States for them; but it should now be actively developed.

The problems of Canada are rather different from those of the other Dominions, since it will clearly be necessary to integrate and co-ordinate its scientific activities with those of the United States to at least as great an extent as with those of the rest of the Commonwealth.

South Africa was first colonized by Dutch farmers when the Dutch East India Company established stations to provide fresh food and supplies for the crews of its ships. They were joined by French Huguenots, and after the British took over in 1806 , by British immigrants, following the Industrial Revolution. Early British rule was unenlightened. and caused a split in the population which endures to this day. The discovery of diamonds and gold, which created a boom, set mining as the second main facet of South African life, the first being agriculture. The population to-day is ten million people. The Africans outnumber the whites by four to one, and the 20 per cent of poor whites among the Europeans constitute a special problem. Only about one fifth of the total population have attained what may be regarded as a minimum standard of life. To raise this level, the production of the country must be raised.

Agriculture, though fairly self-supporting and occupying two thirds of the population, only utilizes 6 per cent of the land surface. This is due to several reasons: bad farming habits, dry soil, excessive evaporation, irregular rains. Moreover, Schwartz has produced evidence in favour of the view that the dryness of South Africa has progressively increased owing to the diversion of great rivers from large 
inland lakes in Bechuanaland to the Indian Ocean and the Atlantic. His remedy was to divert these rivers back into their original courses. This scheme is now once more being considered, together with large-scale irrigating proposals.

Over most of the country, the poverty of the soil makes it more suitable for stock-farming, which, however, brings its own problems of animal disease, parasitic and nutritional. The Veterinary Research Institute at Onderstepoort, probably the largest in the world, is tackling these problems. The country is also well provided with agricultural colleges, experimental farms and research stations. The Low Temperature Station in Cape Town has produced improved methods for preserving and transporting food. Mention should be made of the sugar-cane production of the west sub-tropical belt, with its special experimental and research station. Afforestation is being carried out on a large scale by the Division of Forestry to make up for lack of natural forests ; the Division of Soil and Veld Conservation is coping with problems of erosion and with the education of farmers; the locust has its special research department. Yet much more research is needed before the land can be properly utilized.

The need for industrialization is obvious and urgent, as the gold industry, based as it is on the moribund gold-standard, has a precarious future, and the smaller diamond industry shows signs of reduction in importance. This need can only be solved by the application of science on a much larger scale than at present. However, the supply of trained scientific workers, especially in the physico-chemical sciences, from the four universities of the Union will have to be materially increased to meet this need.

\section{STUDIES OF ATMOSPHERIC POLLEN}

M. H. A. HYDE, keeper of the Department of I Botany in the National Museum of Wales, and Dr. D. A. Williams, of Llandough Hospital, Cardiff, have previously published (New Phytol., 43, 49; 1944) an important census of atmospheric pollens at Cardiff compiled during 1942 as a first publication in their studies of aerial pollen, which they have since termed 'palynology' (see Nature, 155, 264; 1945). In this they showed that, in the aggregate, grass pollens formed 75 per eent of the total pollen deposit caught (by a gravity slide method).

Their observations upon grass pollen have been greatly extended since, and the second part of their "Studies in Atmospheric Pollen" (New Phytol., 44, $83 ; 1945)$ is devoted to the diurnal variation in the incidence of grass pollen which they have demonstrated. Preliminary experiments in 1943 and more detailed experiments in 1944 with the exposure, for two-hourly periods throughout the day and night, of gravity and 'impact' slides (the latter mounted vertically and kept at right-angles to the direction of the wind) are recorded together with relevant meteorological data. The results from a site in good grassland and another upon the hospital roof near by were in good agreement and enable the authors to draw definite conclusions.

The 'impact' catch was always the more sensitive index of the amount of atmospheric pollen, which was found to follow closely the times of mass anthesis of the local grasses when pollen is liberated in large quantities. On fine, sunny days the principal grasses (Festuca rubra and Holcus lanatus) flowered slightly in the morning and profusely in the late afternoon, and this was reflected, immediately, in the relative heights of the pollen maxima which were obtained at these times. On the days when Arrhenatherum elatius, with its early morning anthesis, flowered there was a greater pollen maximum in the morning. Consequently, the time of maximum pollen concentration is likely to depend upon the predominant grass in the neighbourhood. On dull days anthesis was suppressed largely and local pollen concentrations remained low. When such a day was followed by one of bright sunshine exceptionally high concentrations were recorded. Rain may clear the air of pollen.

The authors quote another experiment at St. Mary's Hospital, Paddington, London, and from all their results disagree with Rempe's conclusion that, during day-time, large quantities of pollen are carried to a considerable altitude, and sediment, often at great distances, during the night. They ascribe this disagreement to the different conditions obtaining with tree pollen which formed most of Rempe's samples.

\section{LIFE-HISTORY OF PANDALUS BOREALIS}

THIS prawn is of commercial importance both in Atlantic and Pacific waters. In Norway, researches have been carried on in connexion with its life-history, the latest published results being those of Birger Rasmussen ${ }^{1}$.

Samples were collected continuously from Vigrafjord on the west coast of Norway, during September 1943-May 1944, and the material treated in the same way as in the author's former paper, on prawns from Spitsbergen ${ }^{2}$.

The pelagic larval stages are not dealt with, the smallest prawns caught on the bottom measuring $43.5 \mathrm{~mm}$. in length at the end of September when they are about five months old, and at $1 \frac{1}{2}$ years they have reached a length of $88 \mathrm{~mm}$. Most of these small prawns of $1 \frac{1}{2}$ years are sexually mature males.

The most interesting facts about these prawns are the sex changes. The age-group of $1 \frac{1}{2}$ years old chiefly consists of males spawning for the first time; but a few of these, and the largest individuals, are found in a transitional stage between male and female, maturing later as ovigerous females.

The group of mature males of $1 \frac{1}{2}$ years old at the end of December splits into two, one retaining the male characters, the other changing to a transitional stage later to ripen into females. Here again the larger prawns in the age group become females and the rate of growth after the division is greater in the females than in the remaining males.

The individuals of $2 \frac{1}{2}$ years old which have spawned twice as males during the following winter go over to the transitional stage and gradually change into females which spawn for the first time as females when $3 \frac{1}{2}$ years old.

The population of ovigerous prawns in the Vigrafjord is mainly composed of $2 \frac{1}{2}$ year-old first-time spawners, those of $1 \frac{1}{2}$ and $3 \frac{1}{2}$ years being scarcer. Prawns of $1 \frac{3}{4}$ years old may constitute 92 per cent of the catch and as they become older their number decreases rapidly.

1 Trekk fra dypvannsrekens biologi i norske kystfarvann. I. Vigrafjorden, Møre. Fiskeridirektoratets Skrifter. Serie Investigations. Vol. 8, No. 2. Published by the Director of Investigations. Vol. 8, No. 2. Published by the Director of Figure-texts. (Bergen, 1945.)

${ }^{2}$ Fiskeridirektoratets Skrifter. Serie Havundersgkelser. Vol. 7, No. (1942.) 